\title{
Pattern of Multicultural Insights Development as a Strategy for Adaptation of Midwifery Students
}

\section{Hairuddin $\mathbf{K}^{1^{*}}$ \\ ${ }^{1}$ Universitas Megarezky, Indonesia}

\section{A R T I CLE IN F O}

Article history:

Received July 22, 2021

Revised July 25, 2021

Accepted October 24, 2021

Available online November 25, 2021

Kata Kunci :

Pola, Multikultural, Adaptasi, Interaksi

\section{Keywords:}

Pattern, Multicultural, Adaptation, Interaction

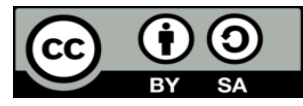

This is an open access article under the $\underline{C C}$ BY-SA license.

Copyright (c) 2021 by Author. Published by Universitas Pendidikan Ganesha

\begin{abstract}
A B S T R A K
Realitas yang tidak dapat dielakkan adalah masyarakat dan bangsa Indonesia terdiri dari berbagai keragaman sosial, suku, budaya, agama, aspirasi politik dan lain-lain sehingga secara sederhana dapat disebut sebagai masyarakat multikultural. Perjumpaan antarbudaya dan kehidupan sosial terkadang berujung pada konflik satu sama lain dan upaya untuk menemukan kompromi sebagai jalan keluar di pihak lain. Realitas ini tidak mengecualikan kehidupan masa lalu, sekarang, dan bahkan masa depan kita. Interaksi dengan orang lain dalam kaitannya dengan budaya, kehidupan sosial bahkan sistem politik dan sistem ekonomi adalah sesuatu yang tidak diragukan lagi menjadi interaksi adalah cara untuk mendapatkan informasi. Penelitian ini bertujuan untuk mengetahui pola, mengetahui proses dan mengetahui faktor pendukung dan penghambat pengembangan wawasan multikultural. Penelitian ini menggunakan metode deskriptif kualitatif melalui observasi, wawancara dan dokumentasi. Uji validitas data menggunakan triangulasi, sedangkan teknik analisis data menggunakan analisis interaktif miles dan Huberman yaitu reduksi, penyajian dan verifikasi atau penarikan kesimpulan data. Hasil penelitian menunjukkan bahwa keragaman budaya, wawasan multikultural dapat meningkatkan pemahaman tentang multikulturalisme Indonesia khususnya mahasiswa kebidanan. Sedangkan proses pengembangan wawasan multikultural menggunakan tahapan formal dan informal, adapun faktor pendukung dan penghambat pengembangan wawasan pada mahasiswa kebidanan diantaranya jiwa kebhinekaan merupakan hal yang mendasar, interaksi dengan mahasiswa di kelas saat mengambil mata kuliah ISBD cukup kondusif untuk penerapan multikultural, ada keseimbangan antara teori dan praktek dan sudah terintegrasi.
\end{abstract}

\begin{abstract}
A B S T R A C T
The inevitable reality is Indonesian people and nation consist of various social diversity, ethnic groups, cultures, religions, political aspirations and others so that it can simply be referred to as a multicultural society. Intercultural encounters and social life sometimes lead to conflict each other and attempts to find a compromise as a way out on the other. This reality does not exclude our past, present and even future lives. Interaction with others in relation to culture, social life and even political systems and economic systems is something that undoubtedly becomes the interaction is the way to get information. This study aims to investigate the pattern, to know the process and to determine the supporting and inhibiting factors for developing multicultural insights. This research used descriptive qualitative method through observation, interviews and documentation. The data validity test used triangulation, while data analysis technique used miles and Huberman interactive analysis, namely reduction, presentation and data verification or conclusion. The results of study showed that diverse cultures, multicultural insights can increase understanding of Indonesian multiculturalism, especially midwifery students. While the process of developing multicultural insights used formal and informal stages, as for the supporting and inhibiting factors of developing insight in midwifery students including the spirit of diversity is fundamental, interaction with students in class when taking ISBD courses is quite conducive to multicultural application, there is a balance between theories and practice and it has been integrated.
\end{abstract}

\section{INTRODUCTION}

The inevitable reality is Indonesian people and nation consist of various social diversity, ethnic groups, cultures, religions, political aspirations and others so that it can simply be referred to as a multicultural society (Setiawan, 2012). Intercultural encounters and social life sometimes lead to conflict each other and attempts to find a compromise as a way out on the other. This reality does not exclude our past, present and even future lives. Interaction with others in relation to culture, social life and even political systems and economic systems is something that undoubtedly becomes the interaction is the way to get information (Sujarwo et al., 2020). No one of community is free from other interactions (Sari, 2019). 
Awareness of multiculturalism has emerged since the Republic of Indonesia was formed and used by the founders of the Indonesian nation to "design the culture of the Indonesian nation. However, for the Indonesian people, the concept of multiculturalism is a new and old concept. Because the awareness of the concept of multiculturalism formed by the founders of this nation that did not materialize during the New order era. This awareness is buried in the name of the unity and stability of the country which later emerged the notion of mono-culturalism which became the main pressure and finally all of them forced a pattern characterized by "uniformity" in various aspects, social, political and cultural systems, so that multiculturalism of Indonesian nation was still very low until now (Setyaningsih, 2005).

Here the researcher gives the term multiculturalism as a key word in understanding the theme of this research discussion. It is defined as the ideas and perspectives of individuals or communities in acting on cultural diversity such as ethnicity, tradition, thought and religion. Multicultural education is "a total school reform effort designed to increase educational equity for a range of cultural, ethnic, and economic groups" (Halim, 2020); and It is important for each student in a multicultural society (Afandi, 2018; Banks \& Banks, 2015; Hadi Cahyono et al., 2017; Zhang, 2017). Multicultural education is a total school reform effort designed to increase educational equity for a range of cultural, ethnic, and economic groups (Zhou \& Kwok, 2019). In globalization era, each state tries to come up with effective educational policies that could suitably frame institutional support systems for education of all students, including those from multicultural families (Lee et al., 2020) and students were able to acquire a deeper level of multicultural awareness (Que, 2017; Smith-Warshaw et al., 2020; Szymanski et al., 2019, 2021). Education is used as a political tool to perpetuate the monopoly power of the education system for certain groups. In other words, multicultural education is a new symptom in the association of human beings who yearn for equal rights, including the right to get the same education for all people, "Education for All" (Surahman, 2010).

On the one hand, this diversity is a beautiful social strength and diversity when another synergizes and works together to build the nation and state. However, on the other hand, if this plurality cannot be managed and nurtured properly it will become a source and trigger for conflict and violence that can shake the joints of national life. Examples of violence and horizontal conflicts that have drained energy and harmed but not only mental and material but sacrificed harmony in Indonesian (Heri Cahyono, 2017). In line with the research results of Muhammad Fahmi conceptually, the meaning of multicultural education at the BBI Islamic Boarding School is no different from the meaning of multicultural education in general, which is teaching mutual respect in diversity. Multicultural education at the BBI Islamic Boarding School has the main capital of tolerance and results in organic tolerance. Practically, multicultural education at the BBI Islamic Boarding School aims to develop tolerance, build equality, harmony, minimize potential conflicts by accepting differences and diversity (Fahmi, 2019). Then, research results of Amalia shows that the adaptation strategy was carried out by students who come from outside Java to survive in Airlangga University environment is to adapt language by means of language accommodation, using technology, and through the social environment besides food adaptation such as conduct food accommodation and cook their own food menus according to taste, then carry out activities and hobbies that you like, contact family, and join in kinship groups (Akhiruddin, A. et al., 2021), and supported by the socio-cultural adaptation, it has a function for Muna ethnic community, namely he function of strengthening identity, the function of the economy, and the function of social solidarity, the adaptation carried out by Muna community in Bitung City. It is a balance that fosters a sense of unity, tolerance and mutual help in society (Hadirman \& Musafar, 2020).

Furthermore, student adaptation is needed. Adaptation of a person is greatly influenced by cultural missions in new areas. It is a personal adjustment to the environment (Arbabi et al., 2017; Hadirman \& Musafar, 2020; Haenni Hoti et al., 2017; Pastore \& Andersen, 2018; Singh, 2017; Ward et al., 2018). Then the phenomena of cross-cultural transition, adaptation, and adjustment have been viewed from a range of perspectives. Although sociocultural adaptation is framed in terms of a culture- learning perspective and is concerned specifically with cultural competence, cross-cultural adjustment in other domains should be part of the same nomological network (Wilson et al., 2017). As mentioned, Black et al have proposed a tripartite model of international adjustment used in research with expatriates which incorporates general, work, and interactional adjustment The multicultural society of this research is understood in the spatial scope of the city (Bitung), which consists of religions, ethnicities, cultures, languages that are different and interact with each other in equality and equality, and have the same rights and opportunities in social life. Adaptation strategies, oral communication patterns, and social interactions allow the community/students to coexist until now they are preserved. This study aims to investigate the pattern of multicultural insights development as an adaptation strategy for midwifery students of Megarezky University. Then the diverse cultures, multicultural insights can increase understanding of Indonesian multiculturalism, especially midwifery students. It is necessary to cultivate mutual respect, mutual respect, cooperate with each other, accept and understand each other, maintain harmony, unity and integrity. The process of developing 
multicultural insights used formal and informal stages, as for the supporting and inhibiting factors of developing insight in midwifery students including the spirit of diversity is fundamental, interaction with students in class when taking ISBD courses is quite conducive to multicultural application. All students understand the multicultural concepts well and there has not been an open mind-set among of the students.

\section{METHODS}

This research used qualitative descriptive method. The goal of qualitative descriptive studies is a comprehensive summarization, in everyday terms, of specific events experienced by individuals or groups of individuals (Lambert \& Lambert, 2013). The research method is basically to obtain data for specific purposes and uses. Data obtained through this research is empirical (observable) data which has certain criteria, namely validity. Valid shows the degree of accuracy between the data that actually occurs on the object and data that the researcher can collect (Arifin, 2020). This method was used to obtain comprehensive data related to the problem being studied (Hairuddin, 2019) namely examining patterns of developing multicultural insights as an adaptation strategy for midwifery students. The informants in this study consisted of Midwifery students of Megarezky University.

The main objective of data collection within this context is to obtain information about the institutional design of public policies. For this, researchers will rely on the reports of participants to reconstruct the'reality' of each national scenario (Seixas et al., 2018). Data collection of qualitative descriptive studies focuses on discovering the nature of the specific events under study (Lambert \& Lambert, 2013). Data collection was carried out using three techniques, namely observation, in-depth interviews, and literature study (Arifin, 2020). Observation is a technique in collecting qualitative data by making direct observations in the field or research environment. This research used participatory observation type. It is a method that aims to obtain complete data. This method is done by making a deep closeness with the midwifery students of Megarezky University as informants in the class. Then in-depth interview, dig into a predetermined topic (based on the purpose and intent of the interview) using openended questions. Excavations were carried out to find out their opinions based on the perspective of the respondents in viewing a problem. This interview technique is carried out by an interviewer by interviewing one person face to face with the respondents (midwifery students of Megarezky University).

\section{RESULT AND DISCUSSION}

\section{Results}

The research finding concerned with multicultural insights of students, especially for students of Midwifery, Megarezky University, had already implemented an education system that has a multicultural concept both the subjects studied, the environmental system built, as well as the social status of each Midwifery Students. The implementation of all Midwifery Students without differentiating from one another, starting from groups such as gender, ethnicity, race, culture, social strata, and even religion. Multicultural education has emphasized students so that they can develop their potential and capacity to the maximum without doing special spaces in themselves and their environment. Based on data collection from observation, in-depth interviews, and literature study. The researcher did interviews to the Midwifery students and lecturer. The terms of interviews about the students think about the implementation of multicultural in ISBD learning material in Midwifery Study Program of Megarezky University. The students responds that Multicultural learning is very important which emphasizes recognition and appreciation of equality for cultural differences because together studying at this campus comes from different cultures, some from Papua, Bima, Toraja, Ternate, Bugis, Raha, Makassar and etc. their opinion regarding the assessment of multicultural education in the Midwifery Study Program at Megarezky University. The assessment of multicultural education can be done through the formation and change of attitudes in students, for example by means of indicators of social care, mutual respect, tolerance for followers of different religions, and so on. Then their view of a lecturer teaching multicultural insights in midwifery study program. It is really support the implementation of multicultural education. The duties of a lecturer are not only required to master and be able to professionally teach the subjects being taught. More than that, an educator must also be able to instil the core values of multicultural education such as democracy, humanism, and pluralism or instil inclusive religious values in students.

From the results of the interview, it can be analyzed that through a diverse culture, multicultural insights can increase understanding of Indonesian multiculturalism, especially midwifery students of Megarezky University. It is necessary to develop mutual respect, mutual respect, cooperate with each other, accept and understand each other, maintain harmony, unity and integrity. Multiculturalism is seen as equality in acting in a country even though there are different ethnicities, races, and religions: Multicultural 
society is not only a concept of ethnic diversity or ethnic culture which characterizes a plural society, but emphasizes cultural diversity in equality: With the concept of multicultural society, it is a relevant topic to be studied because it is in accordance with Indonesia's motto, Bhinneka Tunggal Ika. And the educational potential contained in midwifery students in the classroom as well as with the surrounding plural community cannot be read and used as a strategy to learn from each other and understand the existing plurality. In this paper, they must be able to study other people's cultures and vice versa and not only on the surface, as well as the contribution of diversity to the existence of students (Surahman, 2010). Multicultural insight is a scientific discipline that is being discussed quite warmly in academic circles, as a concept of education that was born in Indonesia in the 21st century shows that there is enough educational discourse in society that is progressive in the future. Therefore, handling is needed to prevent the emergence and development of conflict, namely by building a more inclusive, pluralist, multicultural, humanist, dialogic-persuasive, contextual understanding of diversity through multicultural insights. Multicultural insight seeks to build understanding of the diversity of students with different backgrounds, social status, culture, economy, and so on, so a common perspective and life of democracy must be developed that prioritizes the public interest, and the fact that there are social ties based on differences in ethnicity, religion, customs and regions. The motto of Bhineka Tunggal Ika, which means different things but remains one unity is a concept of strength to realize that the plurality of Indonesia has two potentials at the same time. Two potentials are unity (integrative) and division (dis-integrative) (Lestariningsih \& Purnomo, 2018).

\section{Discussion}

Based on the research results described above, it can be discussed that the process of developing multicultural insights for Midwifery Students is divided into two, namely a formal process and an informal process. The formal process is related to the learning process that occurs in the classroom, while the informal process takes place in the boarding house where the Midwifery Students live. The pattern of developing multicultural insights carried out by students uses two approaches, namely the provision of rewards and punishments. The reward approach is given to midwifery students who have academic achievements, while the punishment or repressive pattern is given to enforce existing rules. Supporting and inhibiting factors can be grouped into two, namely internal and external factors. Internal factors include the spirit that providing an understanding of diversity or multiculturalism is fundamental, the life of Midwifery Students in the dormitory, the balance of theory and practice and has been integrated in the course.

The result of this study was supported by some previous studies stated that the planting of multicultural values in teaching history taught in SMA Negeri 1 Rembang has been done well. The implementation of multicultural values in history learning is not only taught in the classroom, but also through out of class learning. The curriculum becomes an obstacle factor in instilling multicultural values in classroom learning becomes a supported factor in the implementation of multicultural values (Lestariningsih \& Purnomo, 2018). Then, it is line with Lee et al conveyed that multicultural education in its current state would continuously reproduce the existing power dynamics where students from multicultural families are subordinate (Lee et al., 2020). Also, In line with result of research from revealed that there is a diversity such as race, religion, social status, intelligence and the mindset. Although that was different but able to respect and appreciate one another (Akhiruddin, A. et al., 2021). Moreover, this study also stated that external factors include not all teachers or Ustaz who have sufficient knowledge about multiculturalism and the absence of an open-minded mindset. Diversity is very necessary in social life in a pluralistic society, especially in Indonesia. Educational institutions as an ideal educational base must carry the value of diversity and not be monotonous or even closed off.

A multicultural education system that is integrated into the rules and discipline of the boarding school, no permanent placement of Midwifery Students in a hostel, On the other hand, solidarity is one of the forces that can unite and glue the knots of ethnic diversity in a multiethnic, religious, customary and multicultural society. Solidarity emphasizes the state of the relationship between individuals or groups which is based on mutual bonds in life supported by moral values and beliefs that live in society. There is a diversity such as race, religion, social status, intelligence and the mindset. Although it had different but able to respect and appreciate one another. Therefore, given the freedom to actualize themselves in accordance with the identity of each such at the moment and prayed then students who are non-Islamic appreciate Moslem students to pray in the mosque and students who have already rate differentials can adapt to its environment. Islamic Education Teachers cooperation in multicultural education instills so it will not conflict either conflict or conflict batik physical harm themselves and others in a way to disseminate to students.

So that, after learning process, the students got some positive things, the real form of their mutual relationship will give birth to emotional experiences, thereby strengthening the relationship between them. 
They were going to have high sense of solidarity, they will make them strong, at home, and resilient in overseas areas. In our country (Indonesia) should understand the importance of accepting multiculturalism not only de jure but also de facto in people's daily lives (Que, 2017). More specific competencies that will be owned by students through multicultural education, some of the goals that will be developed in students as described by Zamroni are: first, students have strong critical thinking, so they can assess the material presented critically and constructively; second, students have awareness of the nature of being suspicious of others and study why and where suspicion is from. Third, students understand every science is like a double-edged knife, there is a good side and there is a bad side, it all depends on who has the knowledge; fourth, students have the skills to utilize and implement the knowledge they have mastered; fifth, students are a learning person, lifelong learning is still contained in the body, and sixth, students have aspirations to occupy a position as the knowledge learned. But also realizing that this position must be achieved with hard work; seventh, students understand the relationship between what is learned and the conditions and problems at hand (Charles, 2017). Therefore, multiculturalism is a strategy and basis used by society or midwifery students to understand various cultural characteristics in Megarezky University.

\section{CONCLUSION}

Through diverse cultures, multicultural insights can increase understanding of Indonesian multiculturalism, especially midwifery students. Fostering a sense of mutual understanding, maintaining harmony, and unity that we are unity or education for all. While the process of developing multicultural insights uses formal and informal stages, as for the supporting and inhibiting factors of developing insight in midwifery students including the spirit of diversity is fundamental, interaction and adaptation with students in class when they join ISBD courses is quite conducive to multicultural application, there is a balance between theories and practice and has been integrated in ISBD subjects. With the inculcation of this multicultural insight, it is expected that it will facilitate integration between students and other students who come from various different cultural backgrounds. The idea of multiculturalism is not an abstract concept but the development of a pattern of behavior that can only be realized through education. In addition, multiculturalism does not stop at the recognition of the identity of a group of students or a tribe but is also shown the realization of the integration of all students of Megarezky University and even all students in Indonesia.

\section{REFERENCES}

Afandi, M. (2018). Potret Masyarakat Multikultural di Indonesia. Journal Multicultural of IIslamic Education, 2(1), 1-10. https://jurnal.yudharta.ac.id/v2/index.php/ims/article/view/1219.

Akhiruddin, A., Sukmawati, S., Jalal, J., Sujarwo, S., \& Ridwan, R. (2021). Inside-Outside Circle Instructional Model For Multicultural Education. Jurnal Pendidikan Dan Pengajaran, 54(2), 399-405. https://doi.org/10.23887/jpp.v54i2.33191.

Arbabi, K., Yeh, C. J., Mahmud, Z., \& Salleh, A. (2017). From Monocultural to Multicultural: Adaptation of Iranian Immigrant Adolescents in Malaysia. Journal of Adolescent Research, 32(3), 371-402. https://doi.org/10.1177/0743558416630811.

Arifin, Z. (2020). Metodologi Penelitian Pendidikan. Jurnal Al-Hikmah, 1(1), 38. http://alhikmah.stitalhikmahwk.ac.id/index.php/awk/article/view/16.

Banks, J. A., \& Banks, C. M. A. (2015). Multicultural Education: Issues and Perspectives. Wiley/Jossey-Bass Education.

Cahyono, Hadi, Januar, A., \& Dan, M. (2017). Harmoni Masyarakat Tradisi Dalam Kerangka Multikuluralisme. Asketik, 1(1), 27-34. https://doi.org/10.30762/ask.v1i1.408.

Cahyono, Heri. (2017). Pendidikan Multikultural di Pondok Pesantren: Sebagai Strategi dalam Menumbuhkan Nilai Karakter. At-Tajdid: Jurnal Pendidikan Dan Pemikiran Islam, 1(01), 26-43. https://doi.org/10.24127/att.v1i01.333.

Charles. (2017). Pendidikan Multikultural Untuk Memperkuat Kohesifitas Persatuan Dan Kesatuan Bangsa. Journal of Education Studies, 2(1), 29-46. https://doi.org/10.30983/educative.v2i1.319.

Fahmi, M. (2019). Pendidikan Multikultural Sebagai Strategi Adaptasi Pesantren Bali Bina Insani di Daerah Minoritas Muslim Tabanan Bali. UIN Sunan Ampel Surabaya.

Hadirman, \& Musafar. (2020). Fungsi Adaptasi Sosio-Kultural Komunitas Muna Perantauan dalam Masyarakat Multikultural di Kota Bitung Provinsi Sulawesi Utara. Jurnal Sosiologi Agama Indonesia (JSAI), 1(2), 148-160. https://doi.org/10.22373/jsai.v1i2.559.

Haenni Hoti, A., Heinzmann, S., Müller, M., \& Buholzer, A. (2017). Psychosocial Adaptation and School Success of Italian, Portuguese and Albanian Students in Switzerland: Disentangling Migration 
Background, Acculturation and the School Context. Journal of International Migration and Integration, 18(1), 85-106. https://doi.org/10.1007/s12134-015-0461-x.

Hairuddin, K. (2019). Structural intervention problematic of condom usage in Makassar city, Sulawesi Selatan Indonesia. Indian Journal of Public Health Research and Development, 10(10), 1384-1387. https://doi.org/10.5958/0976-5506.2019.03029.8.

Halim, A. (2020). Multikulturalisme Dalam Perspektif Guru Pendidikan Agama Islam (Kajian Interaksi Simbolik pada Musyawarah Guru Mata Pelajaran Pendidikan Agama Islam (MGMP PAI) Kabupaten Mojokerto). In Universitas Islam Malang (Unisma) Malang. http://repository.unisma.ac.id/handle/123456789/717.

Lambert, V. a., \& Lambert, C. E. (2013). Qualitative Descriptive Research: An Acceptable Design. Pacific Rim International Journal of Nursing Research, 16(4), 255-256. https://he02.tcithaijo.org/index.php/PRIJNR/article/download/5805/5064.

Lee, S. J., Jahng, K. E., \& Kim, K. (2020). Light and shade of multicultural education in South Korea: Analysis through Bourdieu's concept of capital. Journal for Multicultural Education, 14(2), 149-161. https://doi.org/10.1108/JME-11-2019-0081.

Lestariningsih, W. A., \& Purnomo, A. (2018). Penanaman Nilai-Nilai Multikultural dalam Pembelajaran Sejarah di SMA Negeri 1 Rembang Tahun Pelajaran 2017/2018. Indonesian Journal of History Education, 6(2), 123-131. https://journal.unnes.ac.id/sju/index.php/ijhe/article/view/27636.

Pastore, L., \& Andersen, M. (2018). Comfort, climatic background and adaptation time: First insights from a post-occupancy evaluation in multicultural workplaces. Proceedings of 10th Windsor Conference: Rethinking Comfort, 814-823. https://infoscience.epfl.ch/record/255269.

Que, S. R. (2017). Masyarakat Multikultural Dalamcerminan Budaya Populer Amerika dan Indonesia. Jurnal Tahuri, 14(10), 14-18. https://ojs3.unpatti.ac.id/index.php/tahuri/article/view/1375.

Sari, I. (2019). Strategi Kebudayaan Pembangunan Keberagamaan di Indonesia: Mempertegas Kontribusi Kearifan Budaya Lokal Dalam Masyarakat Berbhinneka. Studia Sosia Religia, 2(2), 63-77. https://doi.org/10.51900/ssr.v2i2.6487.

Seixas, B. V., Smith, N., \& Mitton, C. (2018). The qualitative descriptive approach in international comparative studies: Using online qualitative surveys. International Journal of Health Policy and Management, 7(9), 778-781. https://doi.org/10.15171/ijhpm.2017.142.

Setiawan, D. (2012). Interaksi Sosial Antar Etnis Di Pasar Gang Baru Pecinan Semarang Dalam Perspektif Multikultural. Journal of Educational Social Studies, $1(1)$. https://journal.unnes.ac.id/sju/index.php/jess/article/view/84.

Setyaningsih, W. (2005). Implementasi Pendekatan Multikultural dalam Upaya Meningkatkan Kesadaran Kebhinekaan Menuju Masyarakat Madani. ENTITA: Jurnal Pendidikan Ilmu Pengetahuan Sosial Dan Ilmu-Ilmu Sosial, 3(1), 65-74. https://doi.org/10.19105/ejpis.v3i1.4647.

Singh, M. K. M. (2017). International EFL/ESL master students' adaptation strategies for academic writing practices at tertiary level. Journal of International Students, 7(3), 620-643. https: //doi.org/10.5281/zenodo.570025.

Smith-Warshaw, J., Georgia, P. C., \& Pinzón-Pérez, H. (2020). Impact of Service-Learning on Latinx College Students Engaged in Intervention Services for the Deaf: Building Multicultural Competence. International Journal of Multicultural Education, 22(3), 50-71. https: //doi.org/10.18251/IJME.V22I3.2413.

Sujarwo, S., Sukmawati, S., Asdar, A., Siradjuddin, S., \& Ariani, N. (2020). University Students' Perception on the Verbal Interaction through WhatsApp Chat Group. Al-Ta Lim Journal, 27(3), 250-257. https://doi.org/10.15548/jt.v27i3.633.

Surahman, S. (2010). Pendidikan Multikultural dalam Kehidupan Mahasiswa Madura di Yogyakarta. SosioReligia, 9(Mei).

Szymanski, M., Alon, I., \& Kalra, K. (2021). Multilingual and multicultural managers' effects on team performance: insights from professional football teams. Multinational Business Review, ahead-ofp(ahead-of-print). https: //doi.org/10.1108/MBR-03-2020-0054.

Szymanski, M., Fitzsimmons, S. R., \& Danis, W. M. (2019). Multicultural managers and competitive advantage: Evidence from elite football teams. International Business Review, 28(2), 305-315. https://doi.org/10.1016/j.ibusrev.2018.10.003.

Ward, C., Ng Tseung-Wong, C., Szabo, A., Qumseya, T., \& Bhowon, U. (2018). Hybrid and Alternating Identity Styles as Strategies for Managing Multicultural Identities. Journal of Cross-Cultural Psychology, 49(9), 1402-1439. https://doi.org/10.1177/0022022118782641.

Wilson, J., Ward, C., Fetvadjiev, V. H., \& Bethel, A. (2017). Measuring Cultural Competencies: The Development and Validation of a Revised Measure of Sociocultural Adaptation. Journal of CrossCultural Psychology, 48(10), 1475-1506. https://doi.org/10.1177/0022022117732721. 
Zhang, W. (2017). Multicultural ethnic music education in Communist China. International Journal of Multicultural Education, 19(3), 65-84. https://doi.org/10.18251/ijme.v19i3.1359.

Zhou, D.-H. R., \& Kwok, H. L. (2019). Multicultural perspectives of help-seeking, stress coping and assessment adaptation. Asia Pacific Journal of Counselling and Psychotherapy, 10(2), 93-94. https://doi.org/10.1080/21507686.2019.1640970. 